\title{
Polypyridyl Ruthenium Complexes: Novel DNA-Intercalating Agents against Human Breast Tumor
}

\author{
João P. Barolli, ${ }^{a}$ Rodrigo S. Corrêa,${ }^{b}$ Fabio S. Miranda, ${ }^{c}$ Juliana U. Ribeiro, ${ }^{a}$ Carlos Bloch Jr., ${ }^{d}$ \\ Javier Ellena, ${ }^{e}$ Virtudes Moreno, ${ }^{f}$ Márcia R. Cominetti ${ }^{g}$ and Alzir A. Batista ${ }^{*, a}$ \\ ${ }^{a}$ Departamento de Química, Universidade Federal de São Carlos, CP 676, 13561-901 São Carlos-SP, Brazil \\ ${ }^{b}$ Departamento de Química, Universidade Federal de Ouro Preto, 35400-000 Ouro Preto-MG, Brazil \\ 'Instituto de Química, Universidade Federal Fluminense, 24020-141 Niterói-RJ, Brazil \\ ${ }^{d}$ Laboratório de Espectrometria de Massa (LEM), EMBRAPA-Recursos Genéticos e Biotecnologia, \\ 70770-917 Brasília-DF, Brazil \\ eInstituto de Física de São Carlos, Universidade de São Paulo, 13560-970 São Carlos-SP, Brazil \\ ${ }^{f}$ Department de Química Inorgànica, Universitat de Barcelona, Martí y Franquès 1-11, \\ 08028 Barcelona, Spain \\ ${ }^{g}$ Departamento de Gerontologia, Universidade Federal de São Carlos, 13565-905 São Carlos-SP, Brazil
}

\begin{abstract}
This paper describes a new series of four DNA-intercalating agents with promising anticancer activities, based on ruthenium(II) with the planar ligand dpqQX (dpqQX = dipyrido[3,2- $\left.a: 2^{\prime}, 3^{\prime}-c\right]$ quinoxaline[2,3-b]quinoxaline). The complexes identified as trans-[ $\left.\mathrm{RuCl}_{2}(\mathrm{dppb})(\mathrm{dpqQX})\right]$, cis-[RuCl$\left.{ }_{2}(\mathrm{dppb})(\mathrm{dpqQX})\right], c t-[\mathrm{RuCl}(\mathrm{CO})(\mathrm{dppb})(\mathrm{dpqQX})] \mathrm{PF}_{6}$ and $c t-\left[\mathrm{RuCl}_{2}\left(\mathrm{PPh}_{3}\right)_{2}(\mathrm{dpqQX})\right]$ (dppb $=1,4$-bis(diphenylphosphine)butane and $\mathrm{PPh}_{3}=$ triphenylphosphine) were characterized by ${ }^{31} \mathrm{P}\left\{{ }^{1} \mathrm{H}\right\}$ nuclear magnetic resonance (NMR) and infrared spectroscopies, cyclic voltammetry, molar conductance measurements, elemental analysis, mass spectrometry and X-ray diffraction analysis for complex $c t$-[RuCl$\left.{ }_{2}\left(\mathrm{PPh}_{3}\right)_{2}(\mathrm{dpqQX})\right]$. Their in vitro cytotoxic activities against MDAMB-213 and MCF-7 breast cancer cells were evaluated and compared with normal L-929 cells. Low drug concentration at which $50 \%$ of the cells are viable relative to the control $\left(\mathrm{IC}_{50}\right)$ values were obtained for all four complexes compared with a reference metallodrug, cisplatin. In addition, DNA affinity studies from titrations, as well as the images obtained by atomic force microscopy (AFM) involving pBR322 plasmid DNA, suggest interactions between the metal complexes and the DNA macromolecule, in which they act as intercalating agents. The intercalation of the complexes with DNA was confirmed by viscosity measurements.
\end{abstract}

Keywords: ruthenium complex, metallo-intercalator, DNA interaction, tumor cells, cytotoxicity

\section{Introduction}

Metal complexes containing a planar polypyridyl ligand obtained from 1,10-phenanthroline have been extensively studied in the last decades due to their DNA binding ability. ${ }^{1-3}$ Specifically, ruthenium(II) complexes coordinated with phenazine and quinoxaline derivatives can bind to DNA through intermolecular forces. The important interactions between the complexes and DNA are electrostatic binding, non-covalent intercalation via

*e-mail: daab@ufscar.br $\pi$-stacking interactions and grooving, leading to hindrance of vital biological functions due to alterations in the tertiary structure of the DNA., ${ }^{4,5}$

Ligands derived from 1,10-phenanthroline present a rigid and planar structure with highly conjugated electron clouds. Many ruthenium(II) complexes with phenazine derivatives have shown promising results as DNA-linkers, interacting with nucleobase pairs of this biomolecule 6,7 and leading to the death of cancer cells. Furthermore, ruthenium complexes with 1,10-phenanthroline derivatives exhibit high redox potential, photochemical and interesting photophysical properties, due to the high energy involved in 
metal-to-ligand charge transfer (MLCT) and, consequently, possible effects upon DNA systems. ${ }^{8,9}$

Previously, Miranda et al. ${ }^{10}$ synthesized three new $\alpha, \alpha$ '-diimine ligands based on 1,10-phenanthroline-5,6-dione condensation with 1,2-phenylenediamine derivatives, using different approaches, including the first example of a dipyrido[3,2-f:2', $\left.3^{\prime}-h\right]$ quinoxalino[2,3- $\left.b\right]$ quinoxaline (dpqQX) heterocyclic system. Recently, we have synthesized several classes of phosphine ruthenium(II) complexes with $N$-heterocyclic ligands and we have evaluated their cytotoxicity against tumor cancer cells, in which promising results have been obtained. ${ }^{11,12}$ Therefore, as part of our ongoing research to obtain new compounds with potential cytotoxic effects, three neutral complexes were obtained with the general formula $\left[\mathrm{RuCl}_{2}(\mathrm{P}-\mathrm{P})(\mathrm{dpqQX})\right]$, where $\mathrm{P}-\mathrm{P}$ is dppb (1,4-bis (diphenylphosphino)butane) or $\left(\mathrm{PPh}_{3}\right)_{2}$ (triphenylphosphine) and dpqQX = dipyrido[3,2-a:2',3'-c] quinoxaline[2,3-b]quinoxaline, a planar heteroaromatic ligand with high electronic conjugation. Also, an ionic compound $c t$ - $[\mathrm{RuCl}(\mathrm{CO})(\mathrm{dppb})(\mathrm{dpqQX})] \mathrm{PF}_{6}$ was synthesized by exchange of a chorine trans to phosphorus to one carbonyl ligand (Scheme 1). All complexes were characterized and their biological properties such as cytotoxicity against invasive MDA-MB 231 and non-invasive MCF-7 tumor cells lines were evaluated, including their interaction with the DNA molecule.

\section{Experimental}

\section{Materials for synthesis}

All manipulations were carried out under purified argon with standard Schlenk techniques. The solvents were degassed and distilled according to standard procedures, where reagent grade solvents were appropriately distilled and dried before use. All chemicals were reagent grade and were used as received from commercial suppliers unless otherwise stated. $\mathrm{RuCl}_{3} \cdot 3 \mathrm{H}_{2} \mathrm{O}, 1,4-$ bis (diphenylphosphino) butane and triphenylphosphine were used as supplied by Sigma-Aldrich. The phosphinic ruthenium precursors

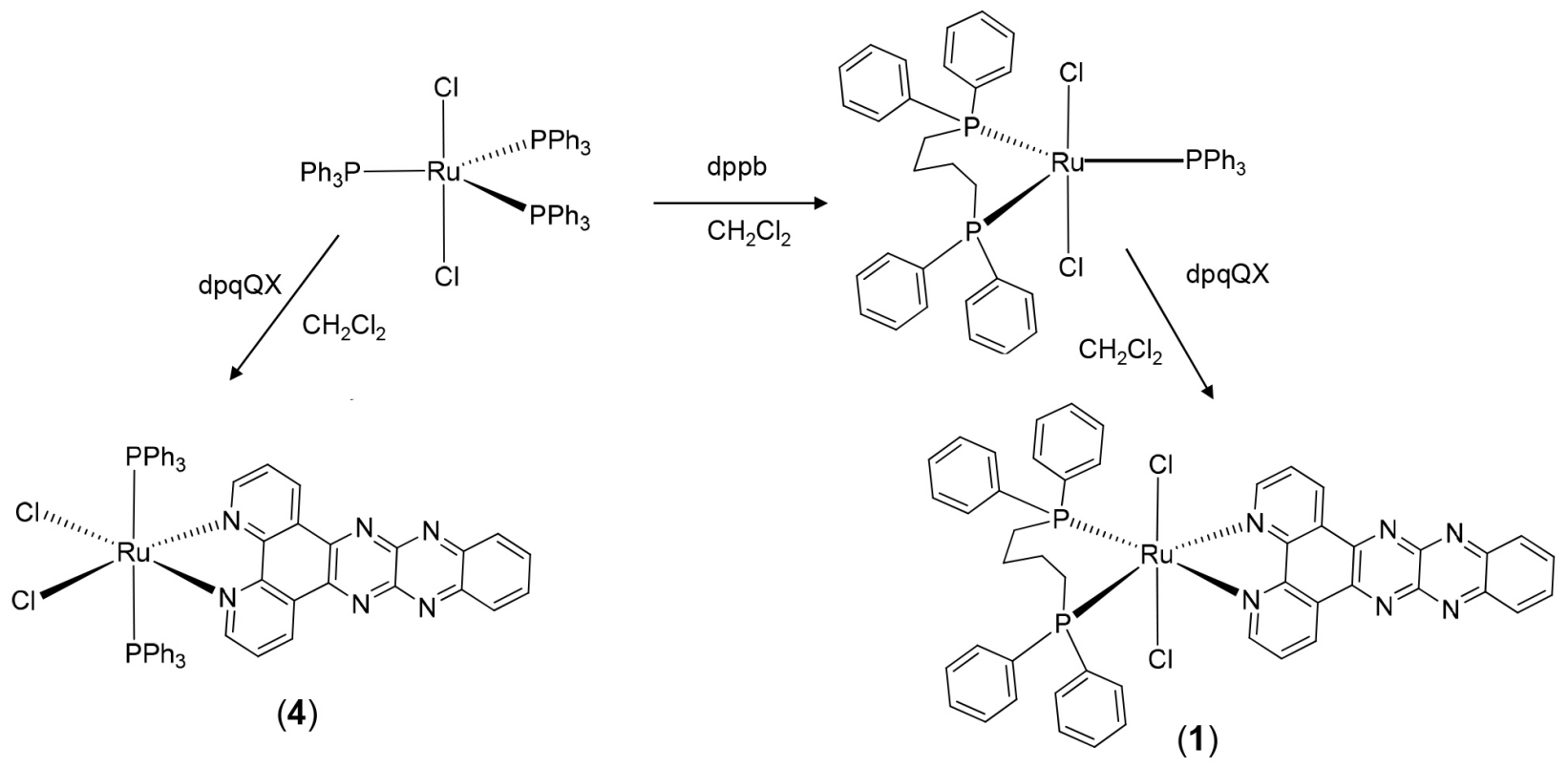

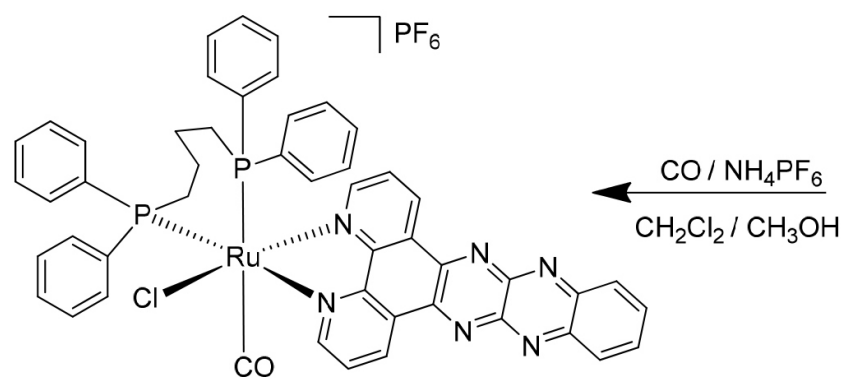

(3)

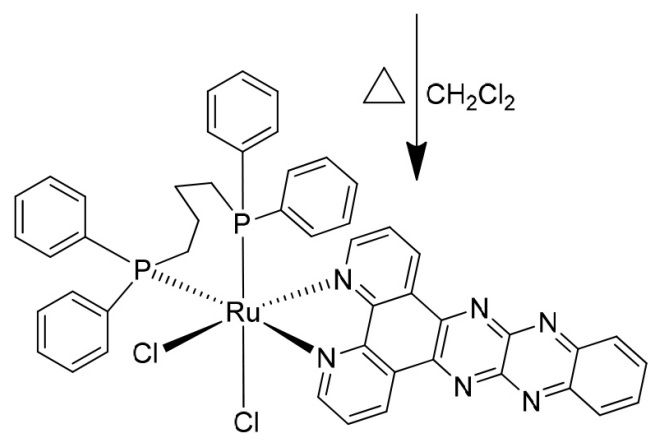

(2)

Scheme 1. Synthetic route of the complexes 1-4. 
$\left[\mathrm{RuCl}_{2}(\mathrm{dppb})\left(\mathrm{PPh}_{3}\right)\right]^{13}$ and $\left[\mathrm{RuCl}_{2}\left(\mathrm{PPh}_{3}\right)_{3}\right]^{14}$ and the dpqQX ligand ${ }^{10}$ were prepared as reported elsewhere.

\section{X-ray diffraction data}

Brown crystals of $c t$-[RuCl$\left.{ }_{2}\left(\mathrm{PPh}_{3}\right)_{2}(\mathrm{dpqQX})\right]$ (compound 4) were grown by slow evaporation of a mixed dichloromethane/ether solution at room temperature. The X-ray diffraction experiment was carried out at $298 \mathrm{~K}$ on an Enraf-Nonius Kappa-CCD diffractometer $(95 \mathrm{~mm}$ CCD camera on goniostat) using graphite monochromated Mo-K $\alpha$ radiation $(0.71073 \AA$ ). The structure was solved by direct methods with SHELXS-97. ${ }^{15}$ The model was refined by full-matrix least squares on $\mathrm{F}^{2}$ with SHELXL-97. ${ }^{15}$ Hydrogen atoms in the aromatic rings of the $\mathrm{PPh}_{3}$ and dpqQX ligands were set as isotropic with a thermal parameter $20 \%$ greater than the equivalent isotropic displacement parameter of the atom to which each one was bonded. Structural analysis and figures were made using the MERCURY ${ }^{16}$ and ORTEP-3 programs. ${ }^{17}$ Although the X-ray experiment afforded the molecular connectivity of compound $\mathbf{4}$, the low quality of the crystals and the disorder associated with the solvent molecules and $\mathrm{PPh}_{3}$ groups prevented complete refinement of the model. Crystal data: $\mathrm{Ru}_{2} \mathrm{C}_{130} \mathrm{H}_{120} \mathrm{C}_{14} \mathrm{~N}_{12} \mathrm{O}_{0.50} \mathrm{P}_{4}, \mathrm{M}_{\mathrm{W}}=2326.20$, monoclinic, $\mathrm{a}=28.859(1) \AA, \mathrm{b}=35.335(3) \AA, \mathrm{c}=25.476(2) \AA$, $\beta=122.209(3)^{\circ}, V=21980.6(5) \AA^{3}, T=298(2) \mathrm{K}$, space group $\mathrm{C}_{2} / \mathrm{c}, \mathrm{Z}=8, \mathrm{D}_{\mathrm{c}}=1.406 \mathrm{~g} \mathrm{~cm}^{-3}, \mu(\mathrm{Mo} \mathrm{K} \alpha)=0.490 \mathrm{~mm}^{-1}$, $\theta$-range for data collection $=2.98-25.00,0 \leq \mathrm{h} \leq 34$, $-0 \leq \mathrm{k} \leq 42,-30 \leq 1 \leq 25,17822$ reflections collected, completeness to $\theta=25^{\circ}$ of $92.0 \%, \mathrm{~F}_{000}=9632,1192$ parameters refined.

\section{Physical measurements}

The IR spectra of the complexes were recorded on a FT-IR Bomem-Michelson 102 spectrometer in the range $4000-200 \mathrm{~cm}^{-1}$ using solid samples pressed in CsI pellets. ${ }^{31} \mathrm{P}\left\{{ }^{1} \mathrm{H}\right\}$ nuclear magnetic resonance (NMR) spectra were recorded at $293 \mathrm{~K}$ using a Bruker Avance III spectrometer, (400 MHz for hydrogen frequency) at $161.98 \mathrm{MHz}$, with $\mathrm{CH}_{2} \mathrm{Cl}_{2}$ as solvent (external reference $85 \% \mathrm{H}_{3} \mathrm{PO}_{4}$ ) and with a capillary containing $\mathrm{D}_{2} \mathrm{O}$. The splitting resonances are defined as $\mathrm{s}=$ singlet or $\mathrm{d}=$ doublet. The molar conductance measurements $(\Lambda)$ were carried out in $\mathrm{CH}_{2} \mathrm{Cl}_{2}$ at $25{ }^{\circ} \mathrm{C}$ using concentrations of $1.0 \times 10^{-3} \mathrm{~mol} \mathrm{~L}^{-1}$ in a Micronal, model B-330, equipped with a Pt electrode. Mass spectra were obtained by direct injection in a MicroTof-Q II Bruker Daltonics Mass Spectrometer (Le) in the positive ion mode, utilizing $\mathrm{CH}_{3} \mathrm{OH}$ (LC-MS grade from Honeywell-B\&J Brand) as solvent. Cyclic voltammetry (CV) experiments were carried out at room temperature in $\mathrm{CH}_{2} \mathrm{Cl}_{2}$ containing $0.1 \mathrm{~mol} \mathrm{~L}^{-1}$ tetrabutylammonium perchlorate (TBAP Fluka Purum) using a BAS-100B/W Bioanalytical Systems Instrument. The working and auxiliary electrodes were stationary Pt foils; the reference electrode was $\mathrm{Ag} / \mathrm{AgCl}$, in a Luggin capillary probe, a medium in which ferrocene $(\mathrm{Fc})$ is oxidized at $0.43 \mathrm{~V}\left(\mathrm{Fc}^{+} / \mathrm{Fc}\right)$. The voltammogram was performed at a scan rate of $0.10 \mathrm{~V} \mathrm{~s}^{-1}$, at $298{ }^{\circ} \mathrm{C}$. The electronic spectra were obtained with scanning on a Hewlett-Packard diode array model 8452A spectrophotometer. The microanalyses were performed at the Microanalytical Laboratory at the Federal University of São Carlos, São Carlos city, São Paulo, using a FISONS CHNS, EA 1108 microanalyser.

\section{Synthesis}

In this work, complexes trans-[RuCl$(\mathrm{dppb})(\mathrm{dpqQX})](\mathbf{1})$ and $c i s-\left[\mathrm{RuCl}_{2}(\mathrm{dppb})(\mathrm{dpqQX})\right]$ (2) differ in respect to the position of the chlorine ligands to each other. For complex $c t$-[RuCl(CO)(dppb)(dpqQX)]PF 6 (3), the first letter of the prefix $c t$ is related to the position of the chlorine to the carbonyl ligand and the second letter refers to the position of the carbonyl relative to the phosphorous atom. For complex $c t$ - $\left[\mathrm{RuCl}_{2}\left(\mathrm{PPh}_{3}\right)_{2}(\mathrm{dpqQX})\right](4)$, the first letter refers to the relative positions of the chlorine atoms with respect to each other and the second refers to the geometric positions of the two $\mathrm{PPh}_{3}$ ligands relative to each other.

The complexes trans-[RuCl$\left.{ }_{2}(\mathrm{dppb})(\mathrm{dpqQX})\right]$ (1) and $c t$ - $\left[\mathrm{RuCl}_{2}\left(\mathrm{PPh}_{3}\right)_{2}(\mathrm{dpqQX})\right](4)$ were obtained from the precursors $\left[\mathrm{RuCl}_{2}(\mathrm{dppb})\left(\mathrm{PPh}_{3}\right)\right]$ and $\left[\mathrm{RuCl}_{2}\left(\mathrm{PPh}_{3}\right)_{3}\right]$, respectively. The complex cis-[RuCl $2(\mathrm{dppb})(\mathrm{dpqQX})]$ (2) was obtained from isomerization of compound $\mathbf{1}$. Compound $c t$-[RuCl(CO)(dppb)(dpqQX) $] \mathrm{PF}_{6}(\mathbf{3})$ was obtained from compound $\mathbf{2}$ by coordination of carbon monoxide, which was generated from the dehydration of formic acid by sulfuric acid.

trans-[RuCl$(\mathrm{dppb})(\mathrm{dpqQX})](\mathbf{1})$

The trans-[RuCl$\left.{ }_{2}(\mathrm{dppb})(\mathrm{dpqQX})\right](\mathbf{1})$ was prepared by reacting the precursor $\left[\mathrm{RuCl}_{2}(\mathrm{dppb})\left(\mathrm{PPh}_{3}\right)\right](0.116 \mathrm{mmol}$; $100 \mathrm{mg}$ ) with dpqQX ligand $(0.116 \mathrm{mmol} ; 38.9 \mathrm{mg})$ in dichloromethane $(50.0 \mathrm{~mL})$ under an Ar atmosphere for $20 \mathrm{~min}$. The final brown solution was concentrated to ca. $3.0 \mathrm{~mL}$ and diethyl ether was added for the precipitation of a brown solid, which was filtered off and washed well with diethyl ether $(3 \times 5.0 \mathrm{~mL})$, and hexane $(3 \times 5.0 \mathrm{~mL})$ and dried under vacuum for 24 hours. Yield: $91 \%$ (98.1 mg); anal. calcd. for $\mathrm{C}_{48} \mathrm{H}_{38} \mathrm{~N}_{6} \mathrm{P}_{2} \mathrm{Cl}_{2} \mathrm{Ru} .0 .33 \mathrm{CH}_{2} \mathrm{Cl}_{2}$ : exptl. (calcd.) \%: C 60.50 (60.40), H4.27 (4.06), N 8.80 (8.74); IR (CsI) v / cm 3051 (m) v(C-H) arom $; 2920$ (w), 2989 (w) 
$v(\mathrm{C}-\mathrm{H})_{\text {aliph }} ; 1587$ (w), $1542(\mathrm{w}), 1494(\mathrm{~m}), 1434$ (s), $1417(\mathrm{~m})$, 1383 (s), 1349 (m), 1315 (w) v(C=N + C=C) + $\delta(\mathrm{C}-\mathrm{H})$; $1114(\mathrm{~m}) \mathrm{v}(\mathrm{P}-\mathrm{C}) ; 1090(\mathrm{~m}) \delta(\mathrm{C}=\mathrm{N}) ; 699$ (s) $\gamma($ aromatic ring); $508(\mathrm{~m}) v(\mathrm{Ru}-\mathrm{P}) ; 425(\mathrm{w}) v(\mathrm{Ru}-\mathrm{N}) ; 317(\mathrm{w})$ $v(\mathrm{Ru}-\mathrm{Cl}) ;{ }^{31} \mathrm{P}\left\{{ }^{1} \mathrm{H}\right\} \mathrm{NMR}\left(161.98 \mathrm{MHz}, \mathrm{CH}_{2} \mathrm{Cl}_{2}\right): \delta 32.6(\mathrm{~s})$; HR TOF-MS-ES: $m / z$ [M $-\mathrm{Cl}]^{+}$calcd.: $897.137 \mathrm{Da}$; found: 897.138 Da; $[\mathrm{M}-\mathrm{H}-2 \mathrm{Cl}]^{2+}$ calcd.: $430.076 \mathrm{Da}$; found: $430.073 \mathrm{Da}$; UV-Vis $\left(\mathrm{CH}_{2} \mathrm{Cl}_{2}, 1.0 \times 10^{-5} \mathrm{~mol} \mathrm{~L}^{-1}\right): \lambda / \mathrm{nm}$ $\left(\varepsilon / \mathrm{L} \mathrm{mol}^{-1} \mathrm{~cm}^{-1}\right) 302\left(2.61 \times 10^{4}\right), 426\left(4.49 \times 10^{3}\right)$. The solid is soluble in dichloromethane, chloroform, methanol, dimethylformamide and dimethylsulfoxide.

\section{cis-[RuCl 2 (dppb)(dpqQX)] (2)}

$\mathrm{A} \mathrm{CH}_{2} \mathrm{Cl}_{2}(100 \mathrm{~mL})$ solution of $1(150 \mathrm{mg}, 0.052 \mathrm{mmol})$ was refluxed for $60 \mathrm{~h}$ under Ar. The resulting brown solution was concentrated to ca. $2 \mathrm{~mL}$ and diethyl ether was added for the precipitation of a brown solid, which was filtered off, washed well with diethyl ether $(3 \times 5.0 \mathrm{~mL})$ and hexane $(3 \times 5.0 \mathrm{~mL})$, and dried under vacuum for 24 hours. Yield: $81 \%$ (43.4 mg); anal. calcd. for $\mathrm{C}_{48} \mathrm{H}_{38} \mathrm{~N}_{6} \mathrm{P}_{2} \mathrm{Cl}_{2} \mathrm{Ru} .0 .33 \mathrm{CH}_{2} \mathrm{Cl}_{2}$ exptl. (calcd.) \%: C 60.50 (60.40), H 4.33 (4.06), N 8.33 (8.74); IR (CsI) $\mathrm{v} / \mathrm{cm}^{-1}: 3053(\mathrm{~m}) \mathrm{v}(\mathrm{C}-\mathrm{H})_{\text {arom }} ; 2923(\mathrm{w}), 2853(\mathrm{w}) \mathrm{v}(\mathrm{C}-\mathrm{H})_{\text {aliph }}$; $1588(\mathrm{w}), 1542(\mathrm{w}), 1496(\mathrm{~m}), 1469(\mathrm{~s}), 1434(\mathrm{~s}), 1418(\mathrm{~m})$, $1384(\mathrm{~s}), 1350(\mathrm{w}), 1312(\mathrm{w}) v(\mathrm{C}=\mathrm{N}+\mathrm{C}=\mathrm{C})+\delta(\mathrm{C}-\mathrm{H})$; 1116 (m) $v(\mathrm{P}-\mathrm{C}) ; 1092(\mathrm{~m}) \delta(\mathrm{C}=\mathrm{N}) ; 697$ (s) $\gamma($ aromatic ring); $507(\mathrm{~m}) \mathrm{v}(\mathrm{Ru}-\mathrm{P}) ; 419(\mathrm{w}) \mathrm{v}(\mathrm{Ru}-\mathrm{N}) ; 302(\mathrm{w})$, 280 (w) v(Ru-Cl); ${ }^{31} \mathrm{P}\left\{{ }^{1} \mathrm{H}\right\}$ NMR $\left(161.98 \mathrm{MHz}, \mathrm{CH}_{2} \mathrm{Cl}_{2}\right)$ : $\delta 43.5$ (d); 30.8 (d), ${ }^{2} \mathrm{Jpp} 33.8 \mathrm{~Hz}$; HR-TOF-MS-ES: $\mathrm{m} / \mathrm{z}[\mathrm{M}-\mathrm{Cl}]^{+}$calcd.: $897.137 \mathrm{Da}$; found: $897.136 \mathrm{Da}$; $[\mathrm{M}-\mathrm{H}-2 \mathrm{Cl}]^{2+}$ calcd: $430.076 \mathrm{Da}$; found: $430.074 \mathrm{Da}$; UV-Vis $\left(\mathrm{CH}_{2} \mathrm{Cl}_{2}, 1.0 \times 10^{-5} \mathrm{~mol} \mathrm{~L}^{-1}\right) \lambda / \mathrm{nm}\left(\varepsilon / \mathrm{M}^{-1} \mathrm{~cm}^{-1}\right)$ $288\left(4.54 \times 10^{4}\right), 424\left(2.97 \times 10^{4}\right)$. The complex 2 is soluble in dichloromethane, chloroform, methanol, dimethylformamide and dimethylsulfoxide.

\section{$c t-[\operatorname{RuCl}(\mathrm{CO})(\mathrm{dppb})(\mathrm{dpqQX})] \mathrm{PF}_{6}(\mathbf{3})$}

The $c t-[\mathrm{RuCl}(\mathrm{CO})(\mathrm{dppb})(\mathrm{dpqQX})] \mathrm{PF}_{6}$ complex was synthesized from compound $c i s-\left[\mathrm{RuCl}_{2}(\mathrm{dppb})(\mathrm{dpqQX})\right](\mathbf{2})$ $(50 \mathrm{mg}, 0.053 \mathrm{mmol})$ dissolved in dichloromethane $(5 \mathrm{~mL})$. The brown solution was exposed to $\mathrm{CO}$ gas generated from a mixture of $\mathrm{H}_{2} \mathrm{SO}_{4} / \mathrm{HCOOH}$, forming a yellow suspension. The mixture was stirred at room temperature and, after the addition of $8.7 \mathrm{mg}$; $(0.053 \mathrm{mmol})$ of $\mathrm{NH}_{4} \mathrm{PF}_{6}$ dissolved in $1.0 \mathrm{~mL}$ of methanol, the resulting yellow solution was concentrated to ca. $2 \mathrm{~mL}$ and diethyl ether was added for the precipitation of a yellow solid, which was filtered off, washed well with diethyl ether $(3 \times 5.0 \mathrm{~mL})$, and hexane $(3 \times 5.0 \mathrm{~mL})$, and dried under vacuum for 24 hours. Yield: $88 \%$ (51.6 mg); anal. calcd. for $\mathrm{C}_{48} \mathrm{H}_{38} \mathrm{ClON}_{6} \mathrm{P}_{3} \mathrm{~F}_{6} \mathrm{Ru} \mathrm{CH}_{2} \mathrm{Cl}_{2}$ exptl. (calcd.) \%: C 51.86 (51.98), H 3.74 (3.49),
N 7.30 (7.27); IR (CsI) $v / \mathrm{cm}^{-1} 3060(\mathrm{~m}) \mathrm{v}(\mathrm{C}-\mathrm{H})_{\text {arom; }}$; 2927 (w), 2851 (w) v(C-H) aliph; 1996 (s) v(CO); 1587 (w), 1542 (w), 1500 (s), 1471 (s), 1436 (s), 1422 (s), 1397 (s), 1386 (s), 1351 (w), 1314 (w) v(C=N + C=C) $+\delta(\mathrm{C}-\mathrm{H})$; $1116(\mathrm{~m}) v(\mathrm{P}-\mathrm{C}) ; 1090(\mathrm{~m}) \delta(\mathrm{C}=\mathrm{N}) ; 844(\mathrm{~s}) v(\mathrm{P}-\mathrm{F})$, 697 (s) $\gamma($ aromatic ring); 558 (s) $\delta(\mathrm{P}-\mathrm{F}), 507$ (m) $v(\mathrm{Ru}-\mathrm{P})$; 427 (w) $v(\mathrm{Ru}-\mathrm{N}) ; 320$ (w) $v(\mathrm{Ru}-\mathrm{Cl}) ;{ }^{31} \mathrm{P}\left\{{ }^{1} \mathrm{H}\right\}$ NMR (161.98 MHz, $\mathrm{CH}_{2} \mathrm{Cl}_{2}$ ): $\delta 36.9$ (d), 7.9 (d), ${ }^{2} J p p 30.0 \mathrm{~Hz}$; HR-TOF-MS-ES $\mathrm{m} / z$ [M $\left.-\mathrm{PF}_{6}\right]^{+}$calcd.: $925.131 \mathrm{Da}$; found: $925.130 \mathrm{Da}$; $\left[\mathrm{M}-\mathrm{CO}-\mathrm{PF}_{6}\right]^{+}$897.137 Da; found: 897.138 Da; UV-Vis $\left(\mathrm{CH}_{2} \mathrm{Cl}_{2}, 1.0 \times 10^{-5} \mathrm{~mol} \mathrm{~L}^{-1}\right) \lambda / \mathrm{nm}$ $\left(\varepsilon / \mathrm{M}^{-1} \mathrm{~cm}^{-1}\right) 298\left(3.14 \times 10^{4}\right), 432\left(1.79 \times 10^{4}\right)$. The complex is soluble in dichloromethane, chloroform, methanol, dimethylformamide and dimethylsulfoxide.

$\mathrm{ct}-\left[\mathrm{RuCl}_{2}\left(\mathrm{PPh}_{3}\right)_{2}(\mathrm{dpqQX})\right](4)$

The complex ct $t$ - $\left.\mathrm{RuCl}_{2}\left(\mathrm{PPh}_{3}\right)_{2}(\mathrm{dpqQX})\right]$ (4) was prepared by stirring the precursor $\left[\mathrm{RuCl}_{2}\left(\mathrm{PPh}_{3}\right)_{3}\right]$ $(0.104 \mathrm{mmol} ; 100 \mathrm{mg})$ with the dpqQX ligand $(0.104 \mathrm{mmol}$; $34.9 \mathrm{mg}$ ) in dichloromethane $(50.0 \mathrm{~mL})$ for $20 \mathrm{~min}$. The final brown solution was concentrated to ca. $2.0 \mathrm{~mL}$ and diethyl ether was added for the precipitation of a brown solid, which was filtered off, washed well with diethyl ether $(3 \times 5.0 \mathrm{~mL})$ and hexane $(3 \times 5.0 \mathrm{~mL})$, and dried under vacuum for 24 hours. Yield: $87 \%$ (93.4 mg); anal. calcd. for $\mathrm{C}_{56} \mathrm{H}_{40} \mathrm{~N}_{6} \mathrm{P}_{2} \mathrm{Cl}_{2} \mathrm{Ru}$ : $0.67 \mathrm{CH}_{2} \mathrm{Cl}_{2}$ : exptl (calc) \%: C 62.39 (62.58), H 3.71 (3.83), N 7.65 (7.73); IR (CsI) v / $\mathrm{cm}^{-1}: 3053(\mathrm{~m}) v(\mathrm{C}-\mathrm{H})_{\text {arom }} ; 1587(\mathrm{w}), 1539(\mathrm{w})$, 1481 (m), 1434 (m), 1419 (m), $1384(\mathrm{~F}), 1346$ (w), $1309(\mathrm{w}) v(\mathrm{C}=\mathrm{N}+\mathrm{C}=\mathrm{C}) ; 1112(\mathrm{~m}) v(\mathrm{P}-\mathrm{C}) ; 1090(\mathrm{~m})$ $\delta(\mathrm{C}=\mathrm{N}) ; 697$ (s) $\gamma($ aromatic ring); $518(\mathrm{~m}) v(\mathrm{Ru}-\mathrm{P}) ; 430(\mathrm{w})$ $v(\mathrm{Ru}-\mathrm{N}) ; 309$ (w), 291 (w) v(Ru-Cl); ${ }^{31} \mathrm{P}\left\{{ }^{1} \mathrm{H}\right\}$ NMR $\left(161.98 \mathrm{MHz}, \mathrm{CH}_{2} \mathrm{Cl}_{2}\right.$ ): $\delta 22.6$ (s); HR-TOF-MS-ES: $m / z\left[\mathrm{M}-\mathrm{Cl}^{-}\right]^{+}$calcd.: $995.152 \mathrm{Da}$; found: $995.158 \mathrm{Da}$; [M - 2 $\left.\mathrm{Cl}^{-}\right]^{2+}$ calcd.: $480.092 \mathrm{Da}$; found: $480.090 \mathrm{Da}$; UV-Vis $\left(\mathrm{CH}_{2} \mathrm{Cl}_{2}, 1.0\right.$ vacuum $\left.10^{-5} \mathrm{~mol} \mathrm{~L}^{-1}\right): \lambda / \mathrm{nm}\left(\varepsilon / \mathrm{M}^{-1} \mathrm{~cm}^{-1}\right) 302$ (2.61 vacuum $\left.10^{4}\right), 436\left(4.49\right.$ vacuum $\left.10^{3}\right)$. The complex is soluble in dichloromethane, chloroform, methanol, ethanol, dimethylformamide and dimethylsulfoxide.

\section{DNA titration}

All the measurements with calf thymus DNA (CT-DNA) were carried out in Tris- $\mathrm{HCl}$ buffer $(5 \mathrm{mM}$ Tris- $\mathrm{HCl}$ and $50 \mathrm{mM} \mathrm{NaCl}, \mathrm{pH}$ 7.4). The CT-DNA concentration per nucleotide was determined by absorption spectrophotometric analysis using the molar absorption coefficient $6.600 \mathrm{M}^{-1} \mathrm{~cm}^{-1}$ at $260 \mathrm{~nm} \cdot{ }^{18,19}$ The spectroscopic titrations were carried out by adding increasing amounts of CT-DNA $(15 \mu \mathrm{L}$, ca. $3 \mathrm{mM})$ to a solution of the complex at a fixed concentration $(2 \mathrm{~mL}, 75 \mu \mathrm{M})$ in a quartz cell, 
and recording the UV-Vis spectra after each addition. While measuring the absorption spectra, an equal amount of CT-DNA was added to the complex solution and the reference solution to eliminate the absorbance of the CT-DNA itself. The complex-DNA affinity was obtained by using the Scatchard equation: ${ }^{19,20}$

$\mathrm{r} / \mathrm{C}_{\mathrm{f}}=\mathrm{nK}(\mathrm{n}-1)$

where $r$ is the number of mol of Ru complex bound to $1 \mathrm{~mol}$ of CT-DNA $\left(\mathrm{C}_{b} / \mathrm{C}_{\mathrm{DNA}}\right), \mathrm{n}$ is the number of equivalent binding sites, and $\mathrm{K}$ is the affinity of the complex for those sites. Concentrations of free $\left(\mathrm{C}_{\mathrm{f}}\right)$ and bound $\left(\mathrm{C}_{\mathrm{b}}\right)$ complexes were calculated from $\mathrm{C}_{\mathrm{f}}=\mathrm{C}(1-\alpha)$ and $\mathrm{C}_{\mathrm{b}}=\mathrm{C}-\mathrm{C}_{\mathrm{f}}$, respectively, where $\mathrm{C}$ is the total concentration of the ruthenium(II) complex. The fraction of bound complex $(\alpha)$ was calculated from:

$\alpha=\left(\mathrm{A}_{\mathrm{f}}-\mathrm{A}\right) /\left(\mathrm{A}_{\mathrm{f}}-\mathrm{A}_{\mathrm{b}}\right)$

where $A_{f}$ and $A_{b}$ are the absorbance of the free and fully bound complex at the selected wavelengths, and $\mathrm{A}$ is the absorbance at any given point during the titration. The plot of $r / C_{f} v s . r$ gives the binding constant $\mathrm{K}_{\mathrm{b}}$ as the slope of the graph.

\section{AFM imaging}

Atomic force microscopy (AFM) samples were prepared by casting a $3-\mu \mathrm{L}$ drop of test solution onto freshly cleaved Muscovite green mica disks as support. The drop was allowed to stand undisturbed for 3 min to favor the adsorbate-substrate interaction. Each DNA-laden disk was rinsed with Milli-Q water and blown dry with clean compressed argon gas directed normal to the disk surface. Samples were stored over silica prior to AFM imaging. All AFM observations were made with a Nanoscope III Multimode AFM (Digital Instrumentals, Santa Barbara, CA). Nano-crystalline Si cantilevers of $125 \mathrm{~nm}$ length with a spring constant of $50 \mathrm{~N} \mathrm{~m}^{-1}$ average ended with conical-shaped $\mathrm{Si}$ probe tips of $10-\mathrm{nm}$ apical radius and cone angle of $35^{\circ}$ were utilized. High-resolution topographic AFM images were collected in air at room temperature (relative humidity $40 \%$ ) on different specimen areas of $2 \times 2 \mu \mathrm{m}$ operating in intermittent contact mode at a rate of $1-3 \mathrm{~Hz}$.

\section{Cell culture assay}

To evaluate the effects of ruthenium complexes on tumor cells, in vitro cytotoxicity assays on human tumor cell lines were performed using a standard method for initial screening of antitumor agents. The complexes were tested against the invasive human breast tumor cell line MDA-MB-231 (ATCC No. HTB-26), the non-invasive breast tumor cell line MCF-7 (ATCC No. HTB-22), and also on a non-tumor line of mouse fibroblasts, L929 (ATCC No. CCL-1). The MDA-MB-231 and L929 cell lines were routinely maintained in Dulbecco's Modified Eagle's medium (DMEM) supplemented with 10\% fetal bovine serum (FBS), and the MCF-7 cell line was cultured in Roswell Park Memorial Institute (RPMI) 1640 medium supplemented with $20 \%$ FBS. All cell lines were kept at $37^{\circ} \mathrm{C}$ in a humidified $5 \% \mathrm{CO}_{2}$ atmosphere. After reaching confluence, cells were detached by trypsinization and $1 \times 10^{4}$ cells well $^{-1}$ were seeded in $200 \mu \mathrm{L}$ of complete medium in 96-well assay microplates (TPP). The plates were incubated at $37^{\circ} \mathrm{C}$ in $5 \% \mathrm{CO}_{2}$ for at least $12 \mathrm{~h}$ to allow cell adhesion prior to drug testing. All tested compounds were dissolved in sterile dimethylsulfoxide (DMSO) (a stock solution with a maximum concentration of $20 \mathrm{mM}$ ) and diluted to 0.05 to $200 \mu \mathrm{M}$ (final concentration in each well), after which $2 \mu \mathrm{L}$ aliquots were added to $200 \mu \mathrm{L}$ of medium (final concentration 1\% DMSO per well). Cells were incubated with compounds for $48 \mathrm{~h}$ at $37^{\circ} \mathrm{C}$ in $5 \%$ $\mathrm{CO}_{2}$.

To verify the potential cytotoxic effects of the complexes, cell viability was measured by the MTT method [3-(4,5-dimethylthiazol-2-yl)-2,5-diphenyltetrazolium bromide], a colorimetric assay wherein the mitochondria of viable cells reduce the soluble yellow tetrazolium salt to blue formazan crystals. ${ }^{21}$ After incubation with the complexes, cells were washed twice with phosphate buffer saline (PBS) and MTT solution $\left(0.5 \mathrm{mg} \mathrm{mL}^{-1}\right.$, $50 \mu \mathrm{L}$ per well) was added to the cells and incubated during 4 hours, after which $100 \mu \mathrm{L}$ of isopropanol was added to dissolve the precipitated formazan crystals. The conversion of MTT to formazan by metabolically viable cells was measured in an automated microplate reader at $595 \mathrm{~nm}$. To analyze the effects of the complexes on cell viability, the viability in the control wells (cells receiving only DMSO) was taken as a reference $(100 \%)$. The viability rates of treated cultures were then expressed as percentages of the control value, and \% cell viability was plotted against drug concentration (logarithmic scale) to determine the $\mathrm{IC}_{50}$ (drug concentration at which $50 \%$ of the cells are viable relative to the control), with the error estimated from the average of three trials. $\mathrm{IC}_{50}$ values were calculated using GraphPad Prism 4.02 software (GraphPad Software, San Diego, CA, USA). ${ }^{22}$

Viscosity measurements were carried out using an Ostwald viscometer immersed in a water bath maintained at 
$25^{\circ} \mathrm{C}$. The DNA concentration in buffer Tris- $\mathrm{HCl}$ was kept constant in all samples, while the complex concentration was increased from 0 to $60 \mu \mathrm{M}$. The flow time was measured at least 5 times with a digital stopwatch and the mean value was calculated. Data are presented as $\left(\eta / \eta_{0}\right)^{1 / 3}$ versus the ratio [complex]/[DNA], where $\eta$ and $\eta_{0}$ are the specific viscosity of DNA in the presence and absence of the complex, respectively. The values of $\eta$ and $\eta_{0}$ were calculated by use of the expression $\left(t-t_{b}\right) / t_{b}$, where $t$ is the observed flow time and $t_{b}$ is the flow time of buffer alone.

\section{Results and Discussion}

\section{Synthesis and characterization of the complexes}

Compounds 1-4 are stable under ambient conditions. They are insoluble in water, hexane, diethyl ether and ethanol, being soluble in methanol, chloroform, dichloromethane, dimethylsulfoxide and dimethylformamide. The purity of the complexes was confirmed by elemental analysis and ${ }^{31} \mathrm{P}\left\{{ }^{1} \mathrm{H}\right\}$ NMR spectra suggesting the formation of trans-[RuCl$(\mathrm{dppb})(\mathrm{dpqQX})](\mathbf{1})$, cis- $\left[\mathrm{RuCl}_{2}(\mathrm{dppb})\right.$ $(\mathrm{dpqQX})](\mathbf{2}), c t-[\mathrm{RuCl}(\mathrm{CO})(\mathrm{dppb})(\mathrm{dpqQX})] \mathrm{PF}_{6}(\mathbf{3})$ and $c t$ - $\left[\mathrm{RuCl}_{2}\left(\mathrm{PPh}_{3}\right)_{2}(\mathrm{dpqQX})\right]$ (4) compounds. ESI-MS(+) spectra showed the isotopic pattern and molecular parent of all the complexes in the study, in agreement with the assigned formulations for mononuclear ruthenium(II) species (Figure S1 in Supplementary Information section). The molar conductivity data in $\mathrm{CH}_{2} \mathrm{Cl}_{2}$ at $25{ }^{\circ} \mathrm{C}$ indicated that only complex $\mathbf{3}$ is a 1:1 electrolyte, while the other compounds are neutral, in accordance with their proposed formulations.

The ${ }^{31} \mathrm{P}\left\{{ }^{1} \mathrm{H}\right\}$ NMR spectra of complexes $\mathbf{2}$ and $\mathbf{3}$ presented typical AX spin systems, two doublets with chemical shifts at 43.5 (d); 30.8 (d), and 36.9 (d); 7.9 (d) ppm, with ${ }^{2} J_{\text {P-P }} 33.8$ and $30.0 \mathrm{~Hz}$, respectively, indicating the formation of asymmetrical structures in which dpqQX is not in the same plane as the dppb ligand. The large difference in the chemical shifts of the phosphorus atoms in the $c t$-[RuCl(CO)(dppb)(dpqQX) $] \mathrm{PF}_{6}(3)$ complex compared with that observed in its precursor, cis-[ $\left.\mathrm{RuCl}_{2}(\mathrm{dppb})(\mathrm{dpqQX})\right](2)$, shows that one phosphorus atom is in the trans-position with respect to the carbonyl group. The shielding observed for one phosphorus atom, which is trans to the carbonyl group in the ${ }^{31} \mathrm{P}\left\{{ }^{1} \mathrm{H}\right\}$ NMR spectra, is due to the trans-weakening caused by the carbonyl to the Ru-P bond, in which this aspect was previously reported. ${ }^{23}$ For complexes $\mathbf{1}$ and $\mathbf{4}$, their ${ }^{31} \mathrm{P}\left\{{ }^{1} \mathrm{H}\right\}$ spectra present a singlet at 32.6 and $22.6 \mathrm{ppm}$, respectively, indicating the formation of symmetrical structures in which the dpqQX ligand is trans to the dppb in (1) or trans to the chlorine in complex 4 . In complex 4 the chemical shift is typical of phosphorous trans phosphorous, such as previously reported for ruthenium/phosphine/diimine complexes. ${ }^{24}$

Cyclic voltammograms of the complexes showed quasi-reversible processes for compounds $\mathbf{1}, \mathbf{2}$ and $\mathbf{4}$ and an irreversible process for complex $\mathbf{3}$ involving oneelectron, corresponding to the oxidation of ruthenium(II) to ruthenium(III) (Table 1).

Table 1. Electrochemical and molar conductivity data for the ruthenium complexes

\begin{tabular}{lcccc}
\hline Complex & $\mathrm{E}_{\mathrm{pa}} / \mathrm{V}$ & $\mathrm{E}_{\mathrm{pc}} / \mathrm{V}$ & $\mathrm{E}_{1 / 2}{ }^{\mathrm{a}} / \mathrm{V}$ & $\begin{array}{c}\Lambda\left(25^{\circ} \mathrm{C}\right) / \\
\left(\mathrm{S} \mathrm{cm}^{2} \mathrm{~mol}^{-1}\right)\end{array}$ \\
\hline $\mathbf{1}$ & 0.72 & 0.56 & 0.64 & 2.1 \\
$\mathbf{2}$ & 0.82 & 0.69 & 0.76 & 2.7 \\
$\mathbf{3}$ & $1.86^{\mathrm{b}}$ & - & - & 21.6 \\
$\mathbf{4}$ & 0.65 & 0.44 & 0.55 & 1.8 \\
\hline
\end{tabular}

aScan rate: $100 \mathrm{mV} \mathrm{s}^{-1}$, in $\mathrm{CH}_{2} \mathrm{Cl}_{2}$ vs. $\mathrm{Ag} / \mathrm{AgCl}$; ${ }^{\mathrm{b}} \mathrm{E}_{\mathrm{pa}}$ : irreversible, in $\mathrm{CH}_{3} \mathrm{CN}$ vs. $\mathrm{Ag} / \mathrm{AgCl} ; \mathrm{E}_{\mathrm{pa}}$ : anodic peak potential; $\mathrm{E}_{\mathrm{pc}}$ : cathodic peak potential; $\Lambda$ : molar conductance (dichloromethane).

The electrochemical oxidation of $\mathbf{3}$ forms a $\mathrm{d}^{5}$ configuration for the ruthenium(III) ion, leading to the dissociation of the CO ligand from the oxidized complex, which explains the irreversibility of the cyclic voltammogram of this compound. As can be seen from Table 1 data the $c i s-\left[\mathrm{RuCl}_{2}(\mathrm{dppb})(\mathrm{dpqQX})\right]$ (2) isomer is electrochemically more stable than the trans isomer, complex 1. This was also previously observed for the $\left[\mathrm{RuCl}_{2}(\mathrm{dppb})(\mathrm{N}-\mathrm{N})\right]\left(\mathrm{N}-\mathrm{N}=\right.$ bipy $=2,2^{\prime}$-bipyridine and 1,10-phenanthroline) complexes. ${ }^{25,26}$ Additionally, the lower oxidation potential for complex 4 can be explained by the competitive effect between the two $\mathrm{PPh}_{3}$ ligands, which are in trans position to each other. ${ }^{24}$

The FTIR band assignments are represented in Table S1. The most characteristic vibrational mode of the free dpqQX ligand is $\mathrm{vC}=\mathrm{N}$ of the phenanthroline and quinoxaline moieties at 1412 and $1384 \mathrm{~cm}^{-1}$, respectively. ${ }^{10}$ The $\mathrm{C}=\mathrm{C}$ skeletal vibrations of the aromatic rings can be observed at 1550 and $1540 \mathrm{~cm}^{-1}$. For all four complexes $v(\mathrm{C}=\mathrm{N})$ stretching appears in the $1500 \mathrm{~cm}^{-1}$ region, indicating that the dpqQX ligand is coordinated. The infrared spectrum of complex 3 shows a typical $\mathrm{vCO}$ band at $1996 \mathrm{~cm}^{-1}$, which is in agreement with a relatively strong interaction (metal-carbonyl back-bonding). The absorptions at $419-430 \mathrm{~cm}^{-1}$ can be assignable to ruthenium-nitrogen bonding, in agreement with the coordination of the dpqQX to ruthenium(II). Additional peaks were observed for complex 3 at 844 and $558 \mathrm{~cm}^{-1}$ due to the $v(\mathrm{P}-\mathrm{F})$ and $\delta(\mathrm{P}-\mathrm{F})$ vibration modes of the anion.

The complex $\mathbf{4}$ crystallizes in the monoclinic system, with space group $\mathrm{C} 2 / \mathrm{c}$ with two molecules in the 
asymmetric unit. The geometry observed for the complex is a distorted octahedron, as can be seen by the bond angles and metal-ligands distances around the ruthenium(II) metal center (Table 2) and its crystal structure is shown in Figure 1. The $\mathrm{N}-\mathrm{Ru}-\mathrm{N}$ bond angle is far from ideal value $\left(90^{\circ}\right)$ due to the five member chelate ring tension. The distances for the $\mathrm{Ru}-\mathrm{Cl}, \mathrm{Ru}-\mathrm{P}$ and $\mathrm{Ru}-\mathrm{N}$ bonds lengths and bond angles found for the compound is within the normal range for similar ruthenium(II) complexes. , $2,25,27^{2}$

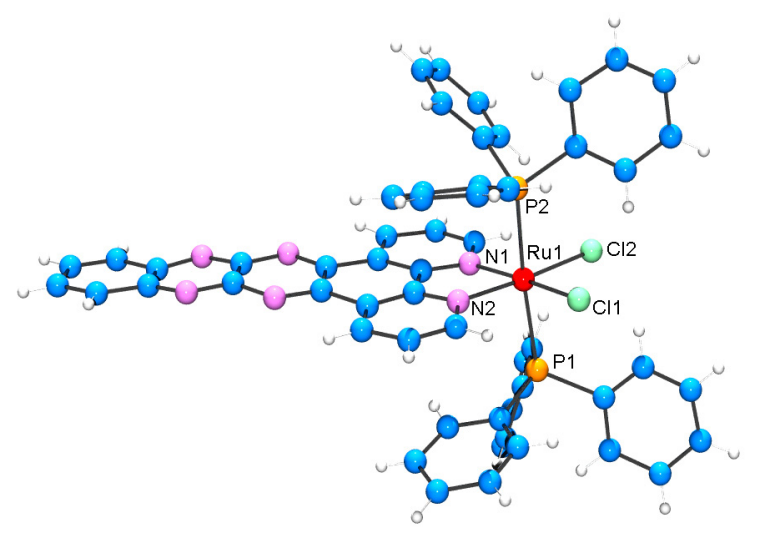

Figure 1. Crystal structure of the complex $\mathbf{4}$ with the main atoms labeled.

In Figure 2A the six rings of the dpqQX ligand labeled (a-f) are depicted. Rings $a$ and $b$ are connected with the ruthenium(II), while rings $c-f$ (tetraaza center) are in the outer-coordination sphere responsible for intermolecular interactions. As can be seen, the $d$ ring is involved in an intermolecular $\pi$ - $\pi$ interaction with the $d$ ring of an adjacent molecule. This interaction in the solid state shows the possibility of this complex binding to DNA by $\pi$-stacking interactions through the tetraaza moiety of the dpqQX (Figure 2B).

\section{DNA binding studies by UV-Vis titration}

UV-Vis experiments were carried out to investigate the ability of the ruthenium(II) complexes (1-4) to bind to calf-thymus DNA (CT-DNA). Electronic spectra showed two bands in the UV region $(280-300 \mathrm{~nm})$ and $(\mathrm{ca} .430 \mathrm{~nm})$

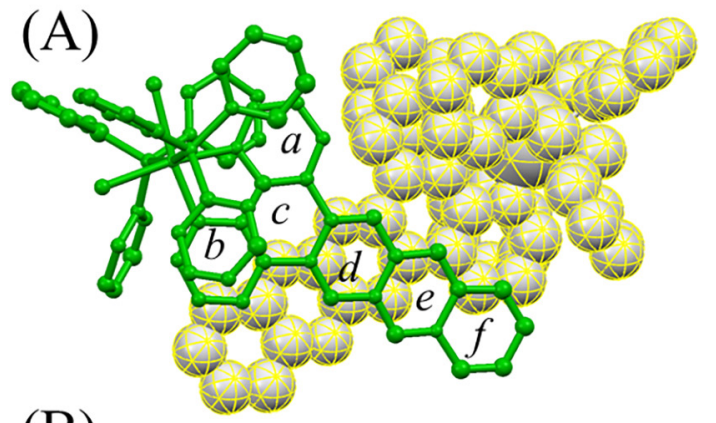

(B)

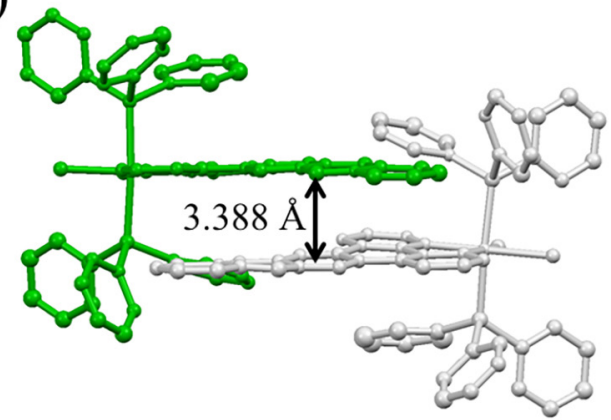

Figure 2. Representation of $\pi-\pi$ interactions occurring in the ligand dpqQX, contributing for crystal packing stabilization of the complex 4 . (A) Ring $d$ involved in the $\pi$-stacking contacts with adjacent molecule; (B) interplanar distance between the dpqQX ligands.

assigned to $\pi \rightarrow \pi^{*}$ ligand charge (LC) transitions, also observed in the free ligands (dppb and dpqQX). The metalto-ligand charge transfer transition is a shoulder band on the ligand centered absorption at ca. $470 \mathrm{~nm}$, and it is assigned to charge transfer from ruthenium(II) to the dpqQX ligand. The influence of CT-DNA on the LC bands of the ruthenium complexes was investigated using UV-Vis spectroscopic titrations and compared to the previously reported data for ruthenium(II)-dppz complexes. ${ }^{28}$ Strong DNA binding by intercalation is suggested for the ruthenium complexes that contain the planar ligand with the largest aromatic surface area, ${ }^{28}$ which is expected to the complexes studied here.

The addition of small amounts of CT-DNA into the complex solution, in buffer, resulted in large hypochromism, MLCT or $\pi \rightarrow \pi^{*}$ absorption bands in compounds (1-4) (see spectra in Supplementary Information section). Table 3 shows that significant levels of hypochromism occur upon addition of DNA to

Table 2. Selected bond lengths and angles for complex $c t-\left[\mathrm{RuCl}_{2}\left(\mathrm{PPh}_{3}\right)_{2}(\mathrm{dpqQX})\right](\mathbf{4})$ with estimated standard deviations in parentheses

\begin{tabular}{|c|c|c|c|c|c|}
\hline & $\begin{array}{l}\text { Bond length / } \\
\text { (Angle / degree) }\end{array}$ & & $\begin{array}{l}\text { Bond length / } \\
\text { (Angle / degree) }\end{array}$ & & $\begin{array}{l}\text { Bond length / } \\
\text { (Angle / degree) }\end{array}$ \\
\hline Ru1-N1 & $2.018(19)$ & N1-Ru1-N(2) & $78.8(7)$ & P1-Ru1-Cl1 & $88.1(2)$ \\
\hline Ru1-N2 & $2.034(17)$ & $\mathrm{N} 1-\mathrm{Ru} 1-\mathrm{Cl}(1)$ & $170.0(5)$ & $\mathrm{P} 1-\mathrm{Ru} 1-\mathrm{Cl} 2$ & $88.9(2)$ \\
\hline $\mathrm{Ru} 1-\mathrm{Cl} 1$ & $2.443(7)$ & $\mathrm{N} 1-\mathrm{Ru} 1-\mathrm{Cl}(2)$ & $93.4(5)$ & P1-Ru1-N2 & $91.7(5)$ \\
\hline $\mathrm{Ru} 1-\mathrm{Cl} 2$ & $2.432(6)$ & N1-Ru1-P(1) & $95.0(5)$ & Cl1-Ru1-P2 & $85.6(2)$ \\
\hline Ru1-P1 & $2.382(7)$ & N1-Ru1-P(2) & $91.5(5)$ & N2-Ru1-P2 & $89.7(5)$ \\
\hline Ru1-P2 & $2.390(7)$ & $\mathrm{P} 1-\mathrm{Ru} 1-\mathrm{P}(2)$ & $173.5(3)$ & $\mathrm{N} 2-\mathrm{Ru} 1-\mathrm{Cl} 2$ & $172.2(5)$ \\
\hline
\end{tabular}


the complexes in study. These types of perturbations are generally considered to arise from the intercalation of the bidentate ligand into the DNA duplex. ${ }^{29}$ By increasing the concentration of the CT-DNA, the intensity of the LC band decreased along with a red shift (Figures 3 and S2 in Supplementary Information section). The complexes $\mathbf{1}$ and $\mathbf{3}$ showed high hypochromicity in both electronic transitions (300 and $432 \mathrm{~nm}$ ).

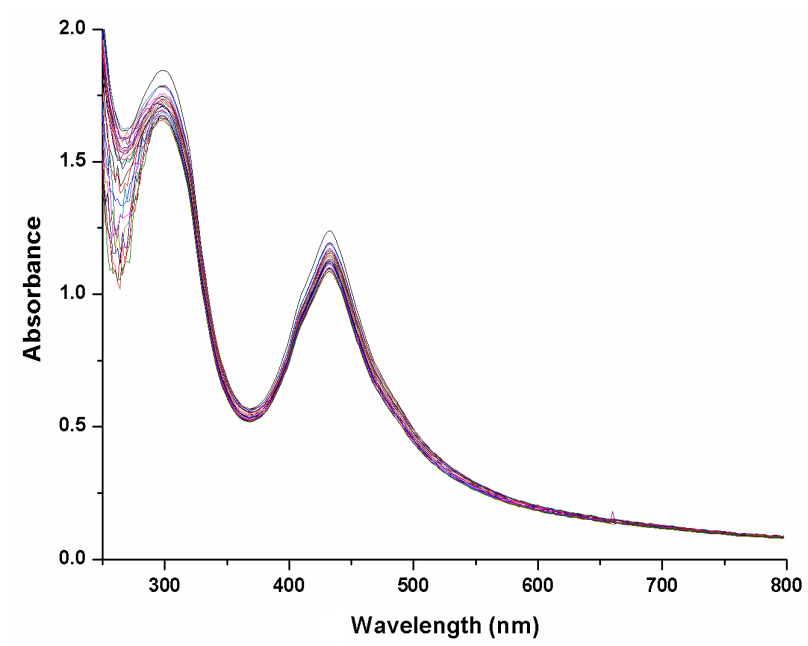

Figure 3. UV-Vis spectra of 2 with increasing amounts $(15 \mu \mathrm{L}$, ca. $3 \mathrm{mM})$ of CT-DNA in Tris- $\mathrm{HCl}$ buffer ( $5 \mathrm{mM}$ Tris- $\mathrm{HCl}$ and $50 \mathrm{mM} \mathrm{NaCl}, \mathrm{pH} 7.4)$, to a solution of the complex at a fixed concentration $(2 \mathrm{~mL}, 75 \mu \mathrm{M})$, in a quartz cell.

The intrinsic binding constants $\left(\mathrm{K}_{\mathrm{b}}\right)$ of complexes were between $10^{5}$ and $10^{6} \mathrm{~L} \mathrm{~mol}^{-1}$ are consistent with intercalation of the complexes with the CT-DNA..$^{30-32}$ The lower values of binding constants for complexes $\mathbf{2}$ and $\mathbf{3}$ may be explained by the positions of the dppb and dpqQX ligands related to each other, which can difficult the intercalation of the complexes to DNA, mainly through the dpqQX ligand. The close values of binding constants between these complexes suggest that the charge of complex $\mathbf{3}$ does not play important role regarding interaction of the complex with DNA. In the same way, the complexes $\mathbf{1}$ and $\mathbf{4}$ present similar binding constants, showing that in this case the different ancillary phosphine ligands do not play important role concerning binding to DNA, probably due to the equatorial position of the dpqQX ligand, allowing better intercalation of these complexes with DNA, when compared with the other two, complexes $\mathbf{2}$ and $\mathbf{3}$.

\section{Atomic force microscopy (AFM) studies}

AFM images were obtained of the DNA plasmid pBR322 as well as pBR322 DNA incubated with each complex or with cisplatin that was used as a reference for the in vitro tests (Figure 4). In these experiments we have
Table 3. Electronic absorption data and interaction constants upon addition of CT-DNA to the solutions of complexes 1-4

\begin{tabular}{lccc}
\hline Complex & $\lambda / \mathrm{nm}$ & $\mathrm{K}_{\mathrm{b}} /\left(\mathrm{L} \mathrm{mol}^{-1}\right)$ & Hypochromism /\% \\
\hline $\mathbf{1}$ & 432 & $7.0 \times 10^{6}$ & 38.4 \\
$\mathbf{2}$ & 432 & $1.4 \times 10^{5}$ & 35.2 \\
$\mathbf{3}$ & 432 & $5.4 \times 10^{5}$ & 37.0 \\
$\mathbf{4}$ & 434 & $2.0 \times 10^{6}$ & 14.3 \\
\hline
\end{tabular}

observed changes in supercoil forms of DNA after 3 hours of incubation at $37^{\circ} \mathrm{C}$. As can be seen, ruthenium complex binding causes DNA chain aggregation (complexes 1, 3 and 4) and supercoiling (complexes 2-4), showing very different DNA morphologies related to untreated DNA. In these complexes, the interaction on the DNA is observed with some formation of agglomerates, also observed previously in palladium(II) and platinum(II) complexes. ${ }^{33}$ The mode of interaction observed for complexes 1-4 can be compared to other ruthenium compounds that intercalate into DNA and also to intercalating organic compounds such as doxorubicin, ethidium bromide and netropsin. ${ }^{34,35}$ The images obtained by AFM show changes in DNA, which are in good agreement with the results of CT-DNA/complex $b$ inding constants. Thus, complex 2 with lower $K_{b}$ value shows a behavior less aggressive against pBR-322 plasmid DNA. The complex $\mathbf{3}$, presenting moderate $\mathrm{K}_{\mathrm{b}}$ value, is more aggressive against pBR-322 plasmid DNA compared with complex $\mathbf{2}$. In addition, the complexes $\mathbf{1}$ and $\mathbf{4}$ with higher $\mathrm{K}_{\mathrm{b}}$ constants show the typical images of intercalating agents.

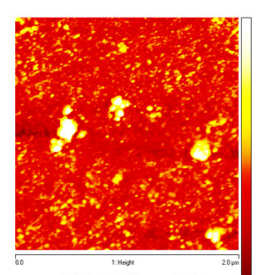

pBR322 + (1)

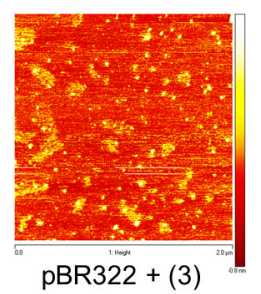

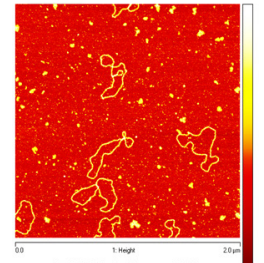

$\mathrm{pBR} 322+(2)$

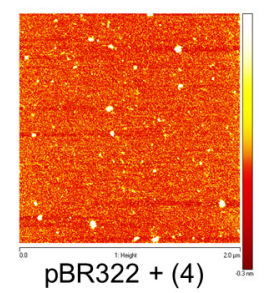

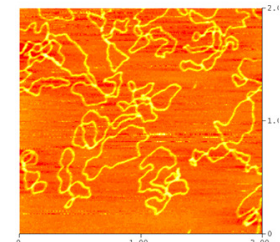

pBR322 free

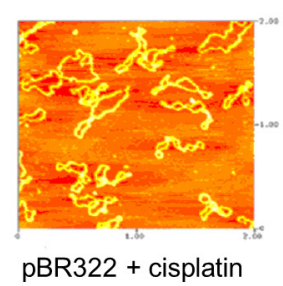

Figure 4. AFM images showing the modifications in pBR322 DNA due to interaction with the ruthenium dpqQX complexes.

Viscosity is very sensitive to the change in the length of the DNA double helix, and it is considered one of the most unambiguous methods to determine intercalation or non-intercalation binding modes of complexes to 
DNA, in solution. ${ }^{36}$ The effect of increasing amounts of complexes on the relative viscosities of CT-DNA is shown in Figure 5, together with thiazole orange, for comparison purpose. The observed increase in the viscosity of the DNA with the increasing of the complex concentration suggests an intercalation of the complexes with the DNA. This behavior is similar to that reported for the complex $\left[\mathrm{Ru}(\mathrm{bpy})_{2}(\mathrm{dppz})\right]^{2+}$, which acts like the classical intercalators ethidium bromide or thiazole orange. ${ }^{37}$

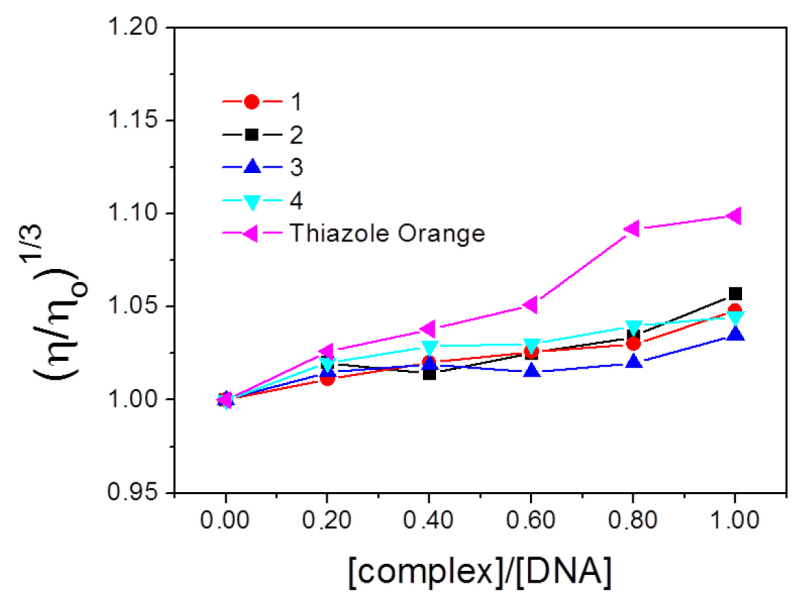

Figure 5. Effect of increasing concentration of the complexes trans-[RuCl$\left.{ }_{2}(\mathrm{dppb})(\mathrm{dpqQX})\right](\mathbf{1}), c i s-\left[\mathrm{RuCl}_{2}(\mathrm{dppb})(\mathrm{dpqQX})\right]$ (2), $c t$ - $[\mathrm{RuCl}(\mathrm{CO})(\mathrm{dppb})(\mathrm{dpqQX})] \mathrm{PF}_{6}(\mathbf{3})$ and $c t-\left[\mathrm{RuCl}_{2}\left(\mathrm{PPh}_{3}\right)_{2}(\mathrm{dpqQX})\right](\mathbf{4})$, on the relative viscosity of CT-DNA at $25^{\circ} \mathrm{C}$.

\section{Antitumoral activity}

The new ruthenium complexes were submitted to cytotoxic assays to study the effects of the complexes on the viability of invasive and non-invasive human breast tumor cells, MDA-MB-231 and MCF-7, respectively, in vitro, by the MTT method. The cells were exposed to each compound for a period of 48 hours in order to allow them to reach the DNA or any other biological target. For comparison, the cytotoxicity of cisplatin was evaluated under the same experimental conditions. $\mathrm{The} \mathrm{IC}_{50}$ values calculated from the dose-survival curves are listed in Table 4.

The new dpqQX ruthenium(II) complexes 1-4 exhibited good activity against the human tumor cell lines MCF-7 and MDA-MB-231. As can be observed from the data represented in Table 4, complex 3 induced more significant cell death than cisplatin (reference metallodrug) in both MDA-MB-231 and MCF-7 tumor cells. Complexes $\mathbf{1}$ and $\mathbf{2}$ are also active, presenting $\mathrm{IC}_{50}$ values comparable with other ruthenium(II)/phosphine complexes. ${ }^{11,12,27}$ The isomer $c i s-\left[\mathrm{RuCl}_{2}(\mathrm{dppb})(\mathrm{dpqQX})\right](\mathbf{2})$ is more active than the trans-[RuCl $2(\mathrm{dppb})(\mathrm{dpqQX})](\mathbf{1})$ one. Probably, due to the lability of the chlorine ligand trans to a phosphorus atom, forming the cationic species $[\mathrm{RuCl}(\mathrm{L})(\mathrm{dppb})(\mathrm{dpqQX})]^{+}$(where $\mathrm{L}=$ solvent), such as occur in analogous complexes. ${ }^{36}$ Therefore, it is relevant to mention that the $c i s-\left[\mathrm{RuCl}_{2}(\mathrm{dppb})(\mathrm{dpqQX})\right]$ complex can be considered pro-drug due to this rapid exchange of one chloride ligand. The complex $c t$ - $\left[\mathrm{RuCl}_{2}\left(\mathrm{PPh}_{3}\right)_{2}(\mathrm{dpqQX})\right]$ (4) is stable in the biological solution, as showed by ${ }^{31} \mathrm{P}\left\{{ }^{1} \mathrm{H}\right\}$ NMR experiments, and it shows better activity than complexes $\mathbf{1}$ and $\mathbf{2}$.

By comparing the cell viability of complexes and free ligands, there was a significant reduction in the cellular viability of complexes than compared the dppb and dpqQX ligands. The cytotoxicity assays showed that complexes $\mathbf{3}$ and $\mathbf{4}$ are the most promising for use against MDA-MB 231 tumor cells. Compared with cisplatin, complex 3 was twenty-four and twenty-two fold more active in the MDA-MB-231 and MCF-7 cell lines, respectively, indicating its potential as an antitumor agent. The increased activity of complex $\mathbf{3}$ could be related to the presence of the carbonyl ligand. We do not exclude the possibility of a parallel mechanism of action involving the release of $\mathrm{CO}$ from the metal center, in which this molecule could play a

Table 4. $\mathrm{IC}_{50}$ values for cytotoxic assays against human breast cancer cells MDA-MB-231, MCF-7 and mouse fibroblasts L929 (non-tumoral cells) for the ruthenium complexes $\mathbf{1 - 4}$, free bases and cisplatin

\begin{tabular}{|c|c|c|c|c|c|}
\hline \multirow{2}{*}{ Complex } & \multicolumn{3}{|c|}{$\mathrm{IC}_{50} / \mu \mathrm{M}$} & \multirow{2}{*}{ IS $^{\mathrm{a}}$} & \multirow{2}{*}{ IS $^{\mathrm{b}}$} \\
\hline & MDA-MB-231 & MCF-7 & L929 & & \\
\hline 1 & $29.09 \pm 3.56$ & $23.75 \pm 2.41$ & $12.65 \pm 0.17$ & 0.43 & 0.53 \\
\hline 2 & $6.02 \pm 0.46$ & $17.05 \pm 0.69$ & $8.22 \pm 0.56$ & 1.36 & 0.48 \\
\hline 3 & $0.10 \pm 0.22$ & $0.41 \pm 0.02$ & $0.32 \pm 0.01$ & 3.90 & 0.78 \\
\hline 4 & $3.14 \pm 0.66$ & $26.11 \pm 0.81$ & $12.26 \pm 1.02$ & 4.02 & 0.47 \\
\hline dpqQX & $>200$ & $>200$ & $0.27 \pm 0.06$ & $<0.01$ & $<0.02$ \\
\hline dppb & $>200$ & $>200$ & N.R. & N.R. & N.R. \\
\hline $\mathrm{PPh}_{3}$ & $>200$ & $>200$ & N.R. & N.R. & N.R. \\
\hline cisplatin & $2.43 \pm 0.20$ & $8.91 \pm 2.60$ & $16.53 \pm 2.38$ & 6.80 & 1.86 \\
\hline
\end{tabular}

${ }^{\mathrm{a}} \mathrm{IS}=\mathrm{IC}_{50}$ L-929/IC $\mathrm{I}_{50}$ MDA-MB-231; ' IS = $\mathrm{IC}_{50}$ L929/IC ${ }_{50}$ MCF-7; N.R.: not realized. 
synergistic role. ${ }^{38}$ Such as the selectivity index corresponds to the ratio between the $\mathrm{IC}_{50}$ value for each compound tested on fibroblasts (normal cell line) and the $\mathrm{IC}_{50}$ value on neoplastic cells, this index can be an initial step toward potential use in subsequent clinical trials.

The fact that $\mathrm{CO}$ is able of interacting with specific biomacromolecules, such as mitochondrial enzymes, cellular membranes and ion channels, showed that the $\mathrm{CO}$ can be a useful molecule for drug design. ${ }^{39,40}$ Thus, metal-complexes containing carbonyl bonds to metals can be a good model for the design of complexes with good anticancer activity. Moreover, it has been shown that the metal-carbonyl complexes, in which the $\mathrm{CO}$ does not dissociate easily in solution, can be pharmacologically active as anticancer agents, indicating that stable metalcarbonyl complexes can be attractive candidates for drug development. ${ }^{41,42}$

Finally, it is worth mentioning that for the evaluation of the complexes on tumor cells the complexes are dissolved in DMSO. Thus, in this case the complex $\mathbf{2}$ can have its chlorido ligand trans to the phosphorus atoms, dissociated, due to the strong trans effect of the phosphorus atoms, as observed previously for the $c i s-\left[\mathrm{RuCl}_{2}(\mathrm{dppb})(\mathrm{bipy})\right]{ }^{36} \mathrm{In}$ this case the species $c i s$-[RuCl(DMSO)(dppb)(bipy)]+ will be formed, which can be detected by ${ }^{31}$ P NMR experiment. To avoid this process the dissolution of the complex in DMSO and its transference to the biological medium has to be done quickly. Thus, in this medium the complex is stable, as confirmed by NMR experiment, for at least $48 \mathrm{~h}$.

\section{Conclusions}

In summary, four new phosphinic ruthenium(II) complexes containing the dpqQX ligand were synthesized and characterized. DNA interaction studies have demonstrated the capability of these complexes to bind DNA and distort its secondary and tertiary structure notably. The DNA/complex binding constants provided by UV-Vis titration showed that the complexes intercalate into the DNA, which suggests their stabilization by $\pi-\pi$ interactions. Antitumor activity assays of the new complexes using the invasive MDA-MB-231 and non-invasive MCF-7 human breast tumor cell lines indicated a good degree of cytotoxicity for all complexes, suggesting they are promising metallodrugs against breast tumor cells.

\section{Supplementary Information}

Supplementary information is available free of charge at http://jbcs.sbq.org.br as a PDF file.

\section{Acknowledgments}

The authors gratefully acknowledge the financial support provided by CAPES/PROEX, CNPq, FAPEMIG, FAPERJ (Process No. E-26-111.177/2011) and FAPESP (Process No. 2012/06013-4). J. P. Barolli thanks FAPESP for a Pos-Doc fellowship (Process No. 2013/21611-8).

\section{References}

1. Bencini, A.; Lippolis, V.; Coord. Chem. Rev. 2010, 254, 2096.

2. Navarro, M.; Betancourt, A.; Hernández, C.; Marchán, E.; J. Braz. Chem. Soc. 2008, 19, 1355.

3. Jiang, G.-B.; Zheng, X.; Yao, J.-H.; Han, B.-J.; Li, W.; Wang, J.; Huang, H.-L.; Liu, Y.-J.; J. Inorg. Biochem. 2014, 141, 170.

4. Haq, I.; Lincoln, P.; Suh, D.; Norden, B.; Chowdhry, B. Z.; Chair, J. B.; J. Am. Chem. Soc. 1995, 117, 4788.

5. Komor, A.; Barton, J.; Chem. Commun. 2013, 49, 3617.

6. Liu, H. K.; Sadler, P. J.; Acc. Chem. Res. 2011, 44, 349.

7. Liu, J. G.; Zhang, Q. L.; Shi, X. F.; Ji, L. N.; Inorg. Chem. 2001, 40, 5045 .

8. Ayers, T.; Caylor, N.; Ayers, G.; Godwin, C.; Hathcock, D. J.; Stuman, V.; Slattery, S.; Inorg. Chim. Acta 2001, 328, 33.

9. Lancaster, K. M.; Gerken, J. B.; Durrel, A. L.; Palmer, J. H.; Gray, H. B.; Coord. Chem. Rev. 2010, 254, 1803.

10. Miranda, F. S.; Signori, A. M.; Vicente, J.; Souza, B.; Priebe, J. P.; Szpoganicz, B.; Goncalves, N. S.; Neves, A.; Tetrahedron 2008, 64, 5410.

11. Lima, B. A. V.; Corrêa, R. S.; Graminha, A. E.; Kuznetsov, A.; Ellena, J.; Pavan, F. R.; Leite, C. Q. F.; Batista, A. A.; J. Braz. Chem. Soc. 2016, 27, 30.

12. Correa, R. S.; de Oliveira, K. M.; Delolo, F. G.; Alvarez, A.; Mocelo, R.; Plutin, A. M.; Cominetti, M. R.; Castellano, E. E.; Batista, A. A.; J. Inorg. Biochem. 2015, 150, 63.

13. Jung, C. W.; Garrou, P. E.; Hoffman, P. R.; Caulton, K. G.; Inorg. Chem. 1984, 23, 726.

14. Stephenson, T. A.; Wilkinson, G. A.; J. Inorg. Nucl. Chem. 1966, $28,945$.

15. Sheldrick, G. M.; Acta Crystallogr., Sect. A: Found. Adv. 2008, 64, 112.

16. Macrae, C. F.; Edgington, P. R.; McCabe, P.; Pidcock, E.; Shields, G. P.; Taylor, R.; Towler, M.; Streek, J. V. D.; J. Appl. Crystallogr. 2006, 39, 453.

17. Farrugia, L. J.; J. Appl. Crystallogr. 1997, 30, 565.

18. McGhee, J. D.; Von Hippel, P. H.; J. Mol. Biol. 1974, 86, 469.

19. Wei, C.; Jia, G.; Yuan, J.; Feng, Z.; Li, C.; Biochemistry 2006, 45,6681 .

20. Sastri, C. V.; Eswaramoorthy, D.; Giribabu, L.; Maiya, B. G.; J. Inorg Biochem. 2003, 94, 138.

21. Mosmann, T.; J. Immunol. Methods 1983, 65, 55. 
22. Skehan, P.; Storeng, R.; Scudiero, D.; Monks, A.; McMahon, J.; Vistica, D.; Warren, J. T.; Bokesch, H.; Kenney, S.; Boyd, M. R.; J. Natl. Cancer Inst. 1990, 82, 1107.

23. Lopes, L. G. F.; Castellano, E. E.; Ferreira, A. G.; Davanzo, C. U.; Clarke, M. J.; Franco, D. W.; Inorg. Chim. Acta 2005, 358, 2883.

24. Batista, A. A.; Santiago, M. O.; Donnici, C. L.; Moreira, I. S.; Healy, P. C.; Berners-Price, S. J.; Queiroz, S. L.; Polyhedron 2001, 20, 2123.

25. Queiroz, S. L.; de Araujo, M. P.; Batista, A. A.; J. Chem. Educ. 2001, 78, 89.

26. Queiroz, S. L.; Batista, A. A.; Oliva, G.; Gambardella, M.; Santos, R. H. A.; MacFarlane, K. S.; Rettig, S. J.; James, B. R.; Inorg. Chim. Acta 1998, 267, 209.

27. Santos, E. R.; Mondelli, M. A.; Pozzi, L. V.; Corrêa, R. S.; Salistre-de-Araújo, H. S.; Pavan, F. R.; Leite, C. Q. F.; Ellena, J.; Malta, V. R. S.; Machado, S. P.; Batista, A. A.; Polyhedron 2013, 51, 292.

28. Biver, T.; Secco, F.; Venturini, M.; Coord. Chem. Rev. 2008, $252,1163$.

29. Pyle, A. M.; Rehmann, J. P.; Meshoyrer. R.; Kumar, C. V.; Turro, N. J.; Barton, J. K.; J. Am. Chem. Soc. 1989, 111, 3051.

30. Menezes, C. S. R.; Costa, L.; Avila, V. D.; Ferreira, M. J.; Vieira, C. U.; Pavanin, L. A.; Homsi-Brandeburgo, M. I.; Hamaguchi, A.; Silveira-Lacerda, E. D.; Chem.-Biol. Interact. 2007, 167, 116.

31. Vilaplana, R. A.; Castineiras, A.; Gonzalez-Vilchez, F.; Bioinorg. Chem. Appl. 2004, 2, 275.
32. Ljubijankić, N.; Zahirović, A.; Turkušić, E.; Kahrović, E.; Croat. Chem. Acta 2013, 86, 215.

33. Tan, L. F.; Chao, H.; Inorg. Chim. Acta 2007, 360, 2016.

34. Ruiz, J.; Lorenzo, J.; Vicente, C.; López, G.; López-deLuzuriaga, J. M.; Monge, M.; Avilés, F. X.; Bautista, D.; Moreno, V.; Laguna, A.; Inorg. Chem. 2008, 47, 6990.

35. Moreno, V.; Lorenzo, J.; Aviles, F. X.; Garcia, M. H.; Ribeiro, J. P.; Morais, T. M.; Florindo, P.; Robalo, P.; Bioinorg. Chem. Appl. 2010, 2010, 1.

36. Monteiro, M. C. R.; Nascimento, F. B.; Valle, E. M. A.; Ellena, J.; Catellano, E. E.; Batista, A. A.; Machado, S. P.; J. Braz. Chem. Soc. 2010, 21, 1992.

37. Macquet, J. P.; Butour, J. L.; Eur. J. Biochem. 1978, 83, 375.

38. Alberto, R.; Motterlini, R.; Dalton Trans. 2007, 1651.

39. Motterlini, R.; Otterbein, L. E.; Nat. Rev. Drug Discovery 2010, 9, 728.

40. Owens, E. O.; Clin. Biochem. 2010, 43, 1183.

41. Petruk, A. A.; Vergara, A.; Marasco, D.; Bikiel, D.; Doctorovich, F.; Estrin, D. A.; Merlino, A.; Inorg. Chem. 2014, 53, 10456.

42. Côrte-Real, L.; Robalo, M. P.; Marques, F.; Nogueira, G.; Avecilla, F.; Silva, T.; Santos, F.; Tomaz, A. I.; Garcia, M. H.; Valente, A.; J. Inorg. Biochem. 2015, 150, 148.

Submitted: September 19, 2016

Published online: February 7, 2017 